\title{
LEADERSHIP SKILL DEVELOPMENTS IN STATISTICS LEARNING
}

\author{
Kazunori Yamaguchi ${ }^{1}$ and Michiko Watanabe ${ }^{2}$ \\ ${ }^{1}$ College of Business, Rikkyo University, Tokyo, Japan \\ ${ }^{2}$ Graduate School of Health Management, Keio University, Kanagawa, Japan \\ kyamagu@rikkyo.ac.jp
}

Rikkyo University started a new program for Statistical leadership development in 2015. Many business schools have leadership development programs and methods. The program is a combination of the business leadership program of College of Business and statistics learning. Repetitions of group works and reflections are expected to motivate students to learn statistics further.

\section{INTRODUCTION}

The Business Leadership Program (BLP) is the core curriculum of the Department of Business, Rikkyo University and encourages students to take an active role in the global community. Through team-based projects and skill-enhancing exercises, BLP nurtures business leadership capabilities in an experience-based learning environment.

The BLP begins with an "Introduction to Leadership" course in the Spring semester of the first year, and concludes with BL4 in the Spring of the third year. This five-semester course of study has a dual approach, using project implementation and skill enhancement to develop leadership. In the semester dedicated to project implementation, students learn to recognize their strengths, and in the succeeding semester dedicated to skill enhancement they work to develop these good points intensively. The cycle continues in the next project implementation semester, where students can check their own progress.

Importance of Statistical leadership is pointed out by Snee and Hoerl (2004). Rodriguez (2012) gave three comments on the statistical leadership as follows. "First, the road to statistical leadership begins with volunteering. Second, successful leaders work on their communication skills and apply them as champions for our field. Third, great leaders encourage and develop younger leaders".

\section{A NEW APPROACH}

Action learning methods may be used for developing leadership skills. Action learning is a process which involves working on real challenges, using the knowledge and skills of a small group of people combined with skilled questioning, to re-interpret old and familiar concepts and produce fresh ideas (see Revans, 1980, 1998). This method can be combined into group works on statistics classes. A combination program of statistics courses, leadership program and action learning will be started in 2015 in Rikkyo University. This program is planned for developing students' problem solving skills using statistical skills as well as leadership skills.

The program is a combination of the leadership development program and statistics learning. Repetitions of group works and reflections are expected to motivate students to learn statistics further. Reflections are important parts for students to find something further to learn.

\section{CONCLUSION}

Details and results will be shown at the conference.

\section{REFERENCES}

Snee, R.D. and Hoerl R.W. (2004). Statistical Leadership, Quality Progress, 2004 October, http://rube.asq.org/quality-progress/2004/10/statistics-roundtable/statistical-leadership.html

Rodrigues, R. (2012). Statistical Leadership: Perspectives of Past Presidents, AMSTATNEWS. 2012 April.

Revans, R. W. (1980). Action learning: New techniques for management. London: Blond \& Briggs, Ltd.

Revans, R. W. (1998). ABC of action learning. London: Lemos and Crane. 